\title{
Protein Kinase C Inhibitors Arrest the C6 Glioma Cell Cycle at a Mid-G1 Phase Restriction Point: Implications for the Antiproliferative Action of Valproate
}

\author{
E. O'BRIEN and C. M. REGAN* \\ Department of Pharmacology, University College, Belfield, Dublin 4, Ireland
}

\begin{abstract}
The teratogenic mechanism(s) of valproate (VPA) have been suggested to arise through inhibition of proliferation coupled with differentiation at a mid-Gl phase restriction point in the cell cycle. As protein kinase $\mathrm{C}$ ( $\mathrm{PKC}$ ) plays a pivotal role in cell proliferation and differentiation, the effect of inhibitors specific for the catalytic and regulatory domains on transit through the G1 phase of the cell cycle was determined. Calphostin $\mathrm{C}$ and bisindolylmaleimide GF $109203 \mathrm{X}$ produced a dose-dependent decrease in proliferation of C6 glioma with approximate $50 \%$ inhibitory concentration values of $10 \mathrm{~nm}$ and $1 \mu \mathrm{M}$, respectively. Flow cytometric analysis indicated proliferative arrest to be in the Gl phase with the expected concomitant decrease of cells in the $\mathrm{G} 2 / \mathrm{M}$ and $\mathrm{S}$ phases. Following release from drug-induced proliferative arrest, cells exhibited a synchronous entry into $S$ phase as evidenced by an increase in $\left[{ }^{3} \mathrm{H}\right]$ thymidine incorporation after approximately $6-8 \mathrm{hr}$, indicating the restriction point to be in the mid-Gl phase. Using mitotically synchronized cells continuously exposed to valproate ( $2 \mathrm{~mm})$, PKC activity was found to be significantly reduced in the mid-Gl phase $(5.5 \mathrm{hr})$ but not at an earlier $(2.5 \mathrm{hr})$ time point, implying VPA to exert its effect at a site upstream to the point of proliferative arrest at 5-6 hr into the Gl phase which as yet, remains to be defined.
\end{abstract}

Abbreviations: $A N O V A=$ analysis of variance; DMEM $=$ Dulbecco's modified Eagle's medium; DMSO = dimethyl sulfoxide; $I_{50}=$ concentration at which $50 \%$ inhibition is achieved; PBS $=$ phosphate buffered saline; $\mathrm{PKC}=$ protein kinase $\mathrm{C}$; PLC $=$ inositol phospholipid-specific phospholipase $\mathrm{C}$; $\mathrm{VPA}=$ valproic acid.

\section{INTRODUCTION}

In vitro studies have demonstrated valproic acid (2propylpentanoate, VPA) to potently inhibit neural cell proliferation rate at concentrations within twice its therapeutic plasma level (Regan, 1985). This antiproliferative action occurs at a defined restriction point in the Gl phase at which cells assume a differentiated phenotype as judged by altered morphology, gene expression and cell substratum adhesivity (Berezin et al., 1996; Martin et al., 1988; Martin and Regan, 1988 and 1991). This antiproliferative effect becomes apparent in the early G1 phase (Martin and Regan, 1991), during which VPA may perturb signal transduction events leading to the eventual accumulation of cells at the mid-G1 restriction point. In part, this involves suppression of transient glycoprotein sialylation required for passage through this phase of the cell cycle, as is reflected by the reduced affinity of exposed cells

*Author for correspondence. for concanavalin A lectin-coated surfaces (Maguire and Regan 1991: unpublished observations).

As VPA sequesters specifically into the neuroepithelium and induces spina bifida during neurulation in both rodent and human populations (Bjerkedal et al., 1982; Dencker et al., 1990; Ehlers et al., 1992; Robert and Guibaud, 1982), this antiproliferative action is likely to result in growth imbalances arising from alterations in differential cell proliferation rates between endodermal and neuroepithelial cell populations. Such differential growth imbalances have been associated with the increased incidence of spina bifida observed in curly tail mutant mouse homozygotes (Copp et al., 1988). The induction of neural tube defects by VPA in vivo is reliant on strict structure-activity requirements, which are independent of anticonvulsant potency (Elmazar et al., 1993; Nau et al., 1991). These require the presence of an $\alpha$-hydrogen atom, a carboxyl function and branching on carbon atom 2 with one chain containing two to four carbon atoms for maximal activity. Similar structural requirements are necessary to concomitantly inhibit 
proliferation and reduce the number of concanavalin A lectin binding sites in C6 glioma (CourageMaguire et al., 1997).

Recent in vitro studies have attributed the antimania qualities of VPA to alterations in signal transduction events (Chen et al., 1994 and 1996). Of particular interest was the observation that chronic exposure of $\mathrm{C} 6$ glioma to VPA resulted in a marked decrease in protein kinase $\mathrm{C}$ (PKC) activity (Chen et al., 1994). This enzyme is distributed ubiquitously and plays a pivotal role in the transduction of external signals operating by activation of receptor-coupled heterotrimeric $G$ proteins via cross-talk mediated by the products of inositol phospholipid-specific phospholipase C (PLC) and adenylyl cyclase (Liu and Simon, 1996). Activation of PLC generates diacylglycerol and inositol-1,4,5trisphosphate, leading to the activation of PKC and the mobilization of intracellular calcium (Berridge, 1993). This pathway appears to play a crucial role in neurulation as inositol deficiency increases susceptibility to neural tube defects in genetically predisposed mouse mutants (Cockroft et al., 1992). As PKC plays a pivotal role in cell proliferation and differentiation (Nishizuka, 1992), the effect of inhibitors specific for the catalytic and regulatory domains on transit through the Gl phase of the cell cycle was determined

\section{MATERIALS AND METHODS}

\section{Cell culture}

The C6 glioma were cultured in Dulbecco's modified Eagle's medium (DMEM; Flow Laboratories, UK) supplemented with $10 \%$ foetal calf serum (Gibco-Biocult, UK), $200 \mathrm{~mm}$ glutamine and $100 \mu \mathrm{g} / \mathrm{ml}$ gentamicin (Sigma Chemical Co. Ltd, UK) and were maintained in a humidified atmosphere of $9 \% \quad \mathrm{CO}_{2}$ at $37^{\circ} \mathrm{C}$. Cells were passaged using $0.025 \%$ trypsin in DMEM. The tissue culture plastics were purchased from Costar (UK). Synchronized populations of C6 glioma were obtained by a mitotic selection procedure (Axelrad and McCulloch, 1957). The loosely adhering and rounded post-mitotic cells were dislodged from the monolayer into the medium by gentle tapping of the culture flask. The cells were gathered by centrifugation and seeded $\left(10^{4}\right.$ cells $\left./ \mathrm{cm}^{2}\right)$ into multiwell plates using fresh medium.

Antiproliferative effects were assessed by direct haemocytometer counting of trypsinized cells or by use of a nuclei counting procedure (Sanford et al., 1951). Freshly trypsinized cells were seeded $\left(10^{4}\right.$ cells $\left./ \mathrm{cm}^{2}\right)$ into $25-\mathrm{cm}^{2}$ flasks for direct cell counting or into multiwell dishes for nuclei counting. The cells were allowed to recover for $24 \mathrm{hr}$ before being exposed to the relevant drug for $48 \mathrm{hr}$. Drugs were dissolved in dimethyl sulfoxide (DMSO), the concentration of which never exceeded $1 \%$ of the tissue culture medium. Following exposure, nuclei counting was performed in duplicate by replacing the medium with $500 \mu \mathrm{l}$ crystal violet $(0.25, \mathrm{w} / \mathrm{v})$ in citric acid $(0.1 \mathrm{M})$. The cells were incubated with this nuclei releasing and staining solution for $30 \mathrm{~min}$ at $37^{\circ} \mathrm{C}$. Then gentle trituration with a Gilson micropipette was performed in order to obtain an even suspension of stained nuclei which were counted using a haemocytometer. Values significantly different $(P<0.05)$ from the control were established by analysis of variance (ANOVA) and Dunnett's post-test.

The length of $S$ phase in cells released from a 48 hr drug exposure period was determined by measuring the point of increased ${ }^{3} \mathrm{H}$-thymidine incorporation during continued culture in full medium under standard conditions of incubation. Briefly, this involved washing the cells with warm DMEM and adding $1 \mu \mathrm{Ci}{ }^{3} \mathrm{H}$-thymidine (sp. act. $26.5 \mathrm{Ci} /$ mmol; Amersham International, UK) to separate duplicate wells for $1 \mathrm{hr}$, every hour. Incorporation of ${ }^{3} \mathrm{H}$-thymidine was determined by solubilizing the cells in $2 \%$ sodium dodecyl sulfate and estimating the number of counts in perchloroacetic acid $(0.5 \mathrm{M})$ precipitates which had been solubilized in $2 \mathrm{M} \mathrm{NaOH}$. Values significantly different $(P<0.05)$ from time zero were established by ANOVA and Dunnett's post-test. Previous pulse chase studies with ${ }^{3} \mathbf{H}$-thymidine have demonstrated populations of cells synchronized by mitotic selection or following exposure to VPA to enter $S$ phase at $11-12 \mathrm{hr}$ and 5-6 hr, respectively, indicating this agent to arrest the cells in the mid-Gl phase of the C6 glioma cell cycle (Martin and Regan, 1991).

\section{Flow cytometric analysis}

The distribution of cells within the various phases of the cell cycle was determined by flow cytometric analysis. Cells were seeded at $2 \times 10^{4}$ cells $/ \mathrm{ml}$ in 25 $\mathrm{cm}^{2}$ tissue culture flasks and were incubated for $24 \mathrm{hr}$ at $37^{\circ} \mathrm{C}$ and $9 \% \mathrm{CO}_{2}$ to allow recovery from the trypsinization procedure. The cells were then incubated with the appropriate agent for a further $48 \mathrm{hr}$, harvested using $0.025 \%$ trypsin, pelleted by centrifugation and fixed using a 70\% ethanol-30\% phosphate buffered saline (PBS) solution for at least $30 \mathrm{~min}$. Subsequently, the cells were pelleted by centrifugation and resuspended in PBS containing RNAase ( $1 \mathrm{mg} / \mathrm{ml}$; Sigma) and the propidium iodide fluorochrome ( $400 \mu \mathrm{g}$; Sigma) which intercalates with DNA. Following incubation at $37^{\circ} \mathrm{C}$ for $30 \mathrm{~min}$ in the dark, the cells were analysed for fluorescence in a Becton Dickinson FacStar Plus processor using an argon-ion laser tuned to $488 \mathrm{~nm}$ Values significantly different $(P<0.05)$ from the control were determined using Student's $t$-test.

\section{Determination of $P K C$ activity}

Enzyme activity was determined separately in both cytosol and particulate fractions using a commercial assay kit (Amersham International, UK) which is based on the catalysed transfer of $\left[\gamma^{32} \mathrm{P}\right] \mathrm{ATP}$ to the threonine group of a peptide acceptor molecule specific for PKC. Samples were 
prepared by washing the adherent cells with Tris$\mathrm{HCl}(30 \mathrm{~mm}), \mathrm{pH} 7.5$, containing $\mathrm{KCl}(125 \mathrm{~mm})$, magnesium acetate $(5 \mathrm{~mm})$, EGTA $(5 \mathrm{~mm})$ and $\beta$ mercaptoethanol (45 mM; Sigma), leupeptin $(2 \mu \mathrm{g}$ / $\mathrm{ml}$; Sigma), benzamidine $(10 \mu \mathrm{M} ; \mathrm{BDH}, \mathrm{UK})$ and aprotinin ( $2 \mu \mathrm{g} / \mathrm{ml}$; Sigma) as protease inhibitors. The cells were then scraped into the above buffer, containing $10 \mathrm{mM} \mathrm{KCl}$, and lysed using low intensity sonication. Nuclei and unbroken cells were removed from the cell lysate by centrifugation ( $1000 \mathrm{rpm} \times 5 \mathrm{~min})$ through the same buffer containing $25 \%$ glycerol and the supernatent was recentrifuged $(100,000 \mathrm{~g} \times 30 \mathrm{~min})$ to obtain the cytosolic and particulate fractions. The latter fraction was solubilized for $1 \mathrm{hr}$ at $4{ }^{\circ} \mathrm{C}$ following high intensity sonication in a $50 \mathrm{~mm}$ Tris $-\mathrm{HCl}$ buffer, $\mathrm{pH} 7.5$, containing EGTA $(10 \mathrm{~mm}), \beta$-mercaptoethanol $(7.7 \mathrm{mM})$, benzamidine $(10 \mu \mathrm{M})$, phenylmethylsulfonyl fluoride ( $1 \mathrm{~mm}$; Sigma), leupeptin $(2 \mu \mathrm{g} / \mathrm{ml})$, aprotinin $(2 \mu \mathrm{g} / \mathrm{ml})$ and $0.1 \%$ Brij 58 (Sigma), centrifuged $(100,000 \mathrm{~g} \times 30 \mathrm{~min})$ and the supernatant retained. PKC activity was determined in 25- $\mu 1$ sample aliquots and was linear over a $0.5-$ $17-\mu \mathrm{g}$ range of protein concentrations, as determined by the method of Bradford (1976). Aliquots of $10 \mu \mathrm{g}$ were used routinely for activity determinations. Enzyme samples prepared from cells exposed to $1 \%$ DMSO served as controls. The activities obtained in the cytosol and particulate fractions were combined to yield total PKC activity and values significantly different $(P<0.05)$ from the control were determined using Student's $t$-test.

\section{RESULTS}

The involvement of $\mathrm{PKC}$ in the regulation of the C6 glioma proliferation rate was determined using calphostin C (Sigma) and bisindolylmaleimide GF 109203X (Calbiochem, UK), which are specific inhibitors of its regulatory and catalytic domains, respectively (Kobayashi et al., 1989; Toullec et al., 1991). Exposure to either agent resulted in a dosedependent decrease in cell proliferation rate in the absence of any apparent cytotoxicity (Fig. 1). Calphostin $\mathrm{C}$ exerted the most potent effect with an approximate $\mathrm{IC}_{50}$ (concentration at which $50 \%$ inhibition is achieved) in the region of $10 \mathrm{~nm}$ and approximately $95 \%$ of the cell population was arrested at the highest concentration evaluated $(20 \mathrm{nM})$. Similar results were obtained with bisindolylmalimide; however, the dose-dependent effect was not as profound as that observed with calphostin C. The $\mathrm{IC}_{50}$ value was approximately $1 \mu \mathrm{M}$ and over $80 \%$ of the cells were arrested with a 10 -fold higher concentration of the drug.

Flow cytometric analysis of drug-arrested cells demonstrated both calphostin C and GF 109203X to exert their effects in the Gl phase of the cell cycle. Using calphostin C (20 nM) the majority of cells $(90 \pm 4 \%)$ were found to reside in the $\mathrm{Gl}$ phase as compared with those of the untreated controls $(66 \pm 1 \%)$. Similarly, GF 109203X (5 mm) arrested $77 \pm 1 \%$ of the cells in the Gl phase. Furthermore, the expected concomitant decrease of cells in the $\mathrm{G} 2 / \mathrm{M}$ and $\mathrm{S}$ phases was observed to be similar using both calphostin $\mathrm{C}(3 \pm 1$ and $4 \pm 2 \%$, respectively) and GF $109203 \mathrm{X} \quad(9 \pm 0.3$ and $9 \pm 0.3 \%$, respectively).

To locate more precisely the point of proliferative arrest in the Gl phase, cells were released from a 48-hr exposure to either calphostin C (20 nM) or GF $109203 X(5 \mu \mathrm{M})$ by washing the cells briefiy with warm DMEM, replacing full medium and determining the time of entry into the $S$ phase using $\left[{ }^{3} \mathrm{H}\right]$ thymidine incorporation as an index (Fig. 2). Cells released from a calphostin $\mathrm{C}$-mediated proliferative arrest exhibited a slow increase in $\left[{ }^{3} \mathrm{H}\right]$ thymidine incorporation after approximately $5-$ $6 \mathrm{hr}$; however, this did not become significant until $8 \mathrm{hr}$. This indicated the restriction point to be located at approximately $6-8 \mathrm{hr}$ into the Gl phase, as this has been demonstrated previously to be 11 $12 \mathrm{hr}$ in duration (Martin and Regan, 1991). In contrast, release from GF 109203X-induced arrest resulted in a synchronous entry into $S$ phase which was significant at $6 \mathrm{hr}$ following release, suggesting
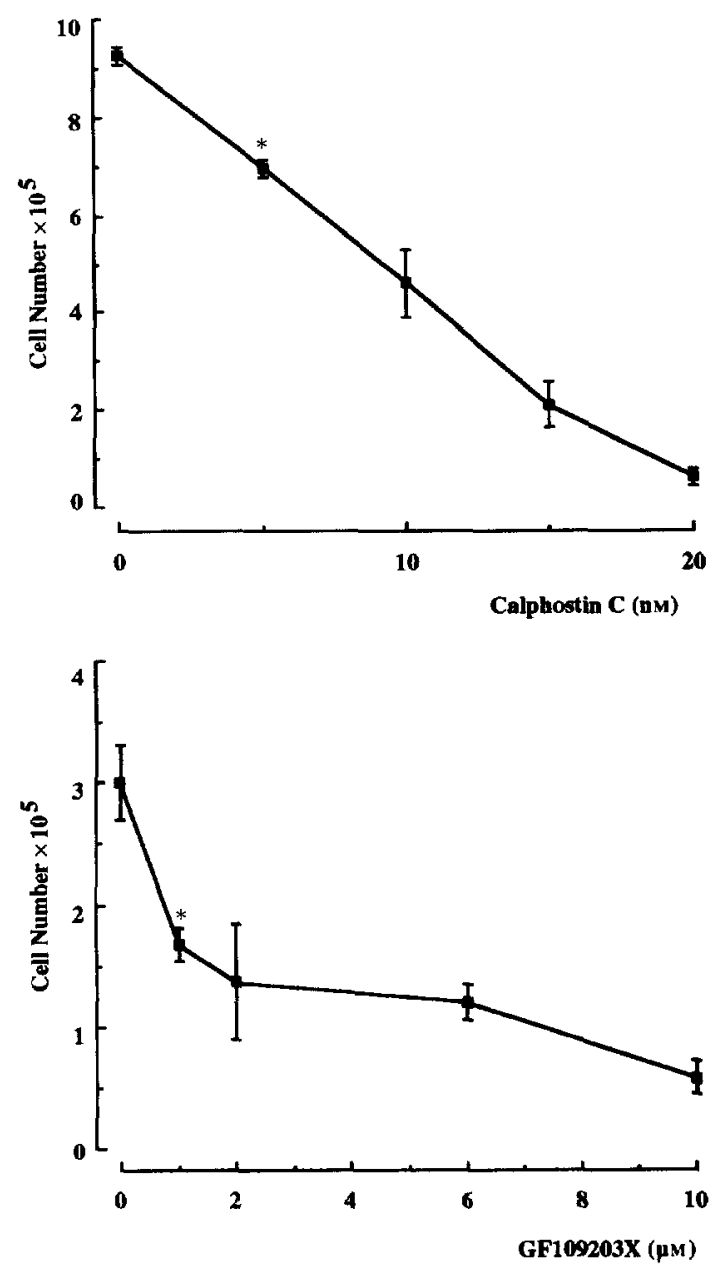

Fig. 1. Dose-dependent effect of PKC inhibitors on the C6 glioma proliferation rate. The values represent the mean \pm SEM $(n=3)$ and the first significant point with respect to the control is indicated with an asterisk. 

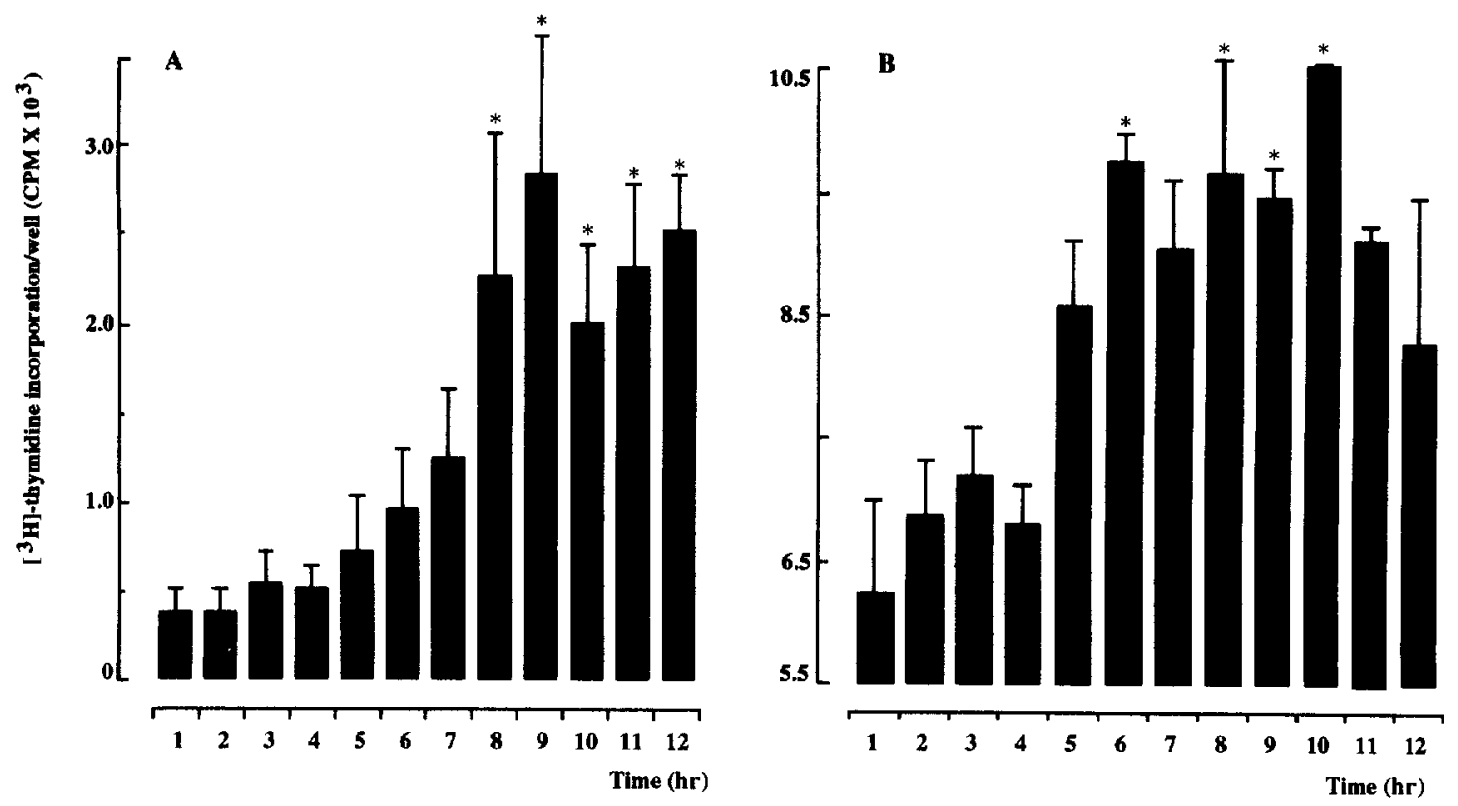

Fig. 2. Time of entry into $\mathrm{S}$ phase following release from proliferative arrest arising from PKC inhibition. Incorporation of $\left[{ }^{3} \mathrm{H}\right]$ thymidine following release from calphostin $\mathrm{C}$ and bisindolylmaleimide GF $109203 \mathrm{X}$ is illustrated in panels $\mathrm{A}$ and $\mathrm{B}$, respectively. The values represent the mean \pm SEM $(n=3)$ and those significantly different from time zero are indicated with an asterisk

the restriction point to be approximately $6 \mathrm{hr}$ into the Gl phase. The ability of GF $109203 X$ to define the point of proliferative arrest more precisely most likely reflects the relative antiproliferative potencies of the PKC inhibitors employed. Cells arrested with the more potent calphostin $C$ inhibitor may be expected to require a longer recovery time for continued passage through $\mathrm{G}$ 1. Collectively, both results suggest a regulatory role for $\mathrm{PKC}$ at a defined restriction point in the mid-Gl phase of the cell cycle.

Given that both PKC inhibitors defined a restriction point similar to that at which VPA exerts a coincident antiproliferative action, the influence of this latter agent on enzyme activity was determined during transit through G1 phase. Using mitotically synchronized cells continuously exposed to VPA ( $2 \mathrm{mM}$ ) or vehicle alone, PKC activity was found to become significantly reduced in the mid-Gl phase $(5.5 \mathrm{hr})$ but not at an earlier $(2.5 \mathrm{hr})$ time point (Fig. 3), implying this agent to exert an indirect inhibitory effect on enzyme activity at its site of proliferative arrest. VPA-induced inhibition of PKC activity was observed only in the cytosol and not in the particulate fraction $(0.12 \pm 0.03 v .0 .12 \pm 0.02$ $\mathrm{pmol}{ }^{32} \mathrm{P}$ transferred $/ \mu \mathrm{g}$ protein/min in VPA-treated and control cells, respectively). Furthermore, particulate activity only accounted for $4 \%$ of total activity which is consistent with that observed by Courage et al. (1995) in A549 lung carcinoma cells.

\section{DISCUSSION}

PKC plays an important role in the transduction of cellular signals elicited by growth factors which play a pivotal role in the regulation of cell prolifer- ation and differentiation (Nishizuka, 1992). As a consequence, it is not surprising that the specific PKC inhibitors employed in this study potently inhibited the $\mathrm{C} 6$ glioma proliferation rate. Calphostin $C$ proved to be a much more effective antiproliferative agent compared with that of GF $109203 \mathrm{X}$, as has been observed for other cell lines (Courage et al., 1995). Flow cytometric analysis

\section{G1 synchronized} cells

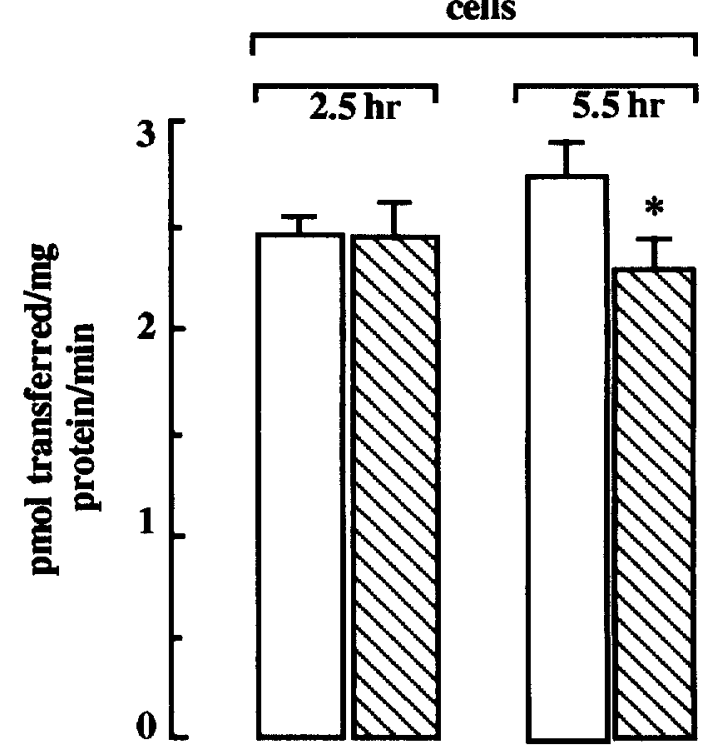

Fig. 3. Influence of VPA on total PKC activity in synchronized cells at increasing times into the G1 phase of the cell cycle. The shaded columns represent activity in the presence of $2 \mathrm{mM}$ valproate. Values are as the mean \pm SEM $(n=3)$ and that significantly different from the control is indicated with an asterisk. 
demonstrated both agents to restrict the cell cycle in the Gl phase, since $80-90 \%$ of the cells accumulated in this phase with a concomitant decrease in those resident in the $\mathrm{G} 2 / \mathrm{M}$ and $\mathrm{S}$ phases.

Proliferative arrest was reversible as removal of either inhibitor resulted in a synchronous entry into $\mathrm{S}$ phase after approximately $6-8 \mathrm{hr}$, thereby defining a PKC-dependent restriction point in the midG1 phase of the cell cycle. Progression through the G1 phase of the cell cycle is remarkably sensitive to protein synthesis inhibition and requires the presence of specific mitogenic growth factors such as platelet-derived growth factor (Zetterberg and Larsson, 1985). Exposure of Swiss 3T3 fibroblasts to this growth factor results an immediate activation of the PKC $\delta$ and $\epsilon$ isoforms and a subsequent steady decline in their expression during late G1 (Olivier and Parker, 1994). These findings support the existence of a PKC restriction point in the $\mathrm{Gl}$ phase of the cell cycle

The proliferative restriction point defined by PKC inhibitors is remarkably similar to that observed with VPA (Martin and Regan, 1991). This occurs in the early $\mathrm{G} 1$ phase and eventually results in an accumulation of cells at the 5-6-hr time point at which they exhibit a differentiated phenotype (Berezin et al., 1996; Maguire and Regan, 1991; Martin et al., 1988; Martin and Regan, 1988 and 1991). At this point a significant decrease in total PKC activity is observed. This appears to be a consequence of proliferative arrest rather than direct inhibition as, in the presence of valproate, enzyme activity remains unaltered during the early $\mathrm{Gl}$ phase. As VPA initiates its antiproliferative effects in the early period ( $1-4 \mathrm{hr}$ ) of the $\mathrm{G} 1$ phase (Martin and Regan, 1991), inhibition of PKC in the mid-Gl phase must arise from a perturbation in upstream signal transduction events which may relate to the ability of VPA to attenuate activation of receptor-coupled heterotrimeric $G$ proteins (Chen et al., 1996). Thus, the concensus opinion emerging is that VPA exerts its effect at a site upstream to the point of proliferative arrest at 5$6 \mathrm{hr}$ into the Gl phase which as yet, remains to be defined.

Acknowledgements-This work was supported by the EU Biotechnology Programme and Forbairt, the Irish Science and Technology Agency.

\section{REFERENCES}

Axelrad A, A. and McCulloch E. A. (1957) Obtaining suspensions of animal cells in metaphase from cultures propagated on glass. Stain Technology 33, 67-71.

Berezin V., Kawa A., Bojic U., Foley A., Nau H., Regan C. M. and Bock E. (1996) Teratogenic potency of valproate analogues evaluated by quantitative estimation of cellular morphology in vitro. Toxicology in Vitro 10, 585-594

Berridge M. J. (1993) Inositol trisphosphate and calcium signalling. Nature 361, 315-325.

Bjerkedal T., Czeizel A., Goujard J., Kallen B., Mastroiacova P., Nevin N., Oakley G. and Robert E. (1982) Valproic acid and spina bifida. Lancet ii, 1096.
Bradford M. M. (1976) A rapid and sensitive method for the quantitation of microgram quantities of protein using the principle of protein-dye binding. Analytical Biochemistry 72, 248-250.

Chen G., Manji H. K., Hawver D. B., Wright C. B. and Potter W. Z. (1996) Effects of valproic acid on betaadrenergic receptors, G-proteins and adenylyl cyclase in rat C6 glioma cells. Neuropsychopharmacology 15, 271280.

Chen G., Manji H. K., Wright C. B., Hawver D. B. and Potter W. Z. (1994) Chronic sodium valproate selectively decreases protein kinase $\mathrm{C} \alpha$ and $\varepsilon$ in vitro. Journal of Neurochemistry 63, 2361-2364.

Cockroft D. L., Brook F. A. and Copp A. J. (1992) Inositol deficiency increases the susceptibility to neural tube defects in genetically predisposed (curly tail) mouse embryos in vitro. Teratology 45, 223-232.

Copp A. J., Brook F. A. and Roberts H. J. (1988) A celltype-specific abnormality of cell proliferation in mutant (curly tail) mouse embryos developing spinal neural tube defects. Development 104, 285-295.

Courage C., Budworth J. and Gescher A. (1995) Comparison of ability of protein kinase $\mathrm{C}$ inhibitors to arrest cell growth and to alter cellular protein kinase $\mathrm{C}$ localisation. British Journal of Cancer 71, 697-704.

Courage-Maguire C., Bacon C. L., Regan C. M. and Nau H. (1997) Correlation of in vitro anti-proliferative potential with in vivo teratogenicity in a series of valproate analogues. International Journal of Developmental Neuroscience 15, 37-43 (see also erratum, 15, 693-694).

Dencker L., Nau H. and D'Argy R. (1990) Marked accumulation of valproic acid in embryonic neuroepithelium of the mouse during early organogenesis. Teratology 41, 699-706.

Ehlers K., Sturje H., Merker H. J. and Nau H. (1992) Valproic acid-induced spina bifida: a mouse model. Teratology 45, 145-154.

Elmazar M. M. A., Hauck R. S. and Nau H. (1993) Anticonvulsant and neurotoxic activities of twelve analogues of valproic acid. Journal of Pharmaceutical Sciences 82, 1255-1258.

Kobayashi E., Nakano H., Morimoto M. and Tamaoki T. (1989) Calphostin C (UCN-1028C), a novel microbial compound, is a highly potent and specific inhibitor of protein kinase C. Biochemical and Biophysical Research Communications $159,548-553$.

Liu M. and Simon M. I. (1996) Regulation by cAMPdependent protein kinase of a G-protein-mediated phospholipase C. Nature 382, 83-87.

Maguire C. and Regan C. M. (1991) In vitro screening for anticonvulsant-induced teratogenesis: drug alteration of cell adhesivity. International Journal of Developmental Neuroscience 9, 581-586.

Martin M. L. and Regan C. (1988) The anticonvulsant sodium valproate specifically induces the expression of a rat glial heat shock protein which is identified as the collagen type IV receptor. Brain Research 459, 131-137.

Martin M. L. and Regan C. M. (1991) The anticonvulsant valproate teratogen restricts the glial cell cycle at a defined point in the mid-Gl phase. Brain Research 554, 223-228.

Martin M. L., Breen K. C. and Regan C. M. (1988) Perturbations of cellular functions integral to neural tube formation by the putative teratogen sodium valproate. Toxicology in Vitro 2, 43-48.

Nau H., Hauck R. S. and Ehlers K. (1991) Valproic acidinduced neural tube defects in mouse and human: aspects of chirality, alternative drug development, pharmacokinetics and possible mechanisms. Pharmacology and Toxicology 69, 310-321.

Nishizuka Y. (1992) Intracellular signalling by hydrolysis of phospholipids and activation of PKC. Science 258, 607-614.

Olivier A. R. and Parker P. J. (1994) Bombesin, plateletderived growth factor, and diacylglycerol induce selective membrane association and down-regulation of pro- 
tein kinase $\mathrm{C}$ isotypes in Swiss 3T3 cells. Journal of Biological Chemistry 269, 2758-2763.

Regan C. M. (1985) Therapeutic levels of sodium valproate inhibit mitotic indices in cells of neural origin. Brain Research 347, 394-398.

Robert E. and Guibaud P. (1982) Maternal valproic acid and congenital neural tube defects. Lancet ii, 937.

Sanford K. K., Earle W. R., Evans B. J., Waltz H. K. and Shannon J. E. (1951) The measurement of proliferation in tissue culture by enumeration of cell nuclei. Journal of the National Cancer Institute 11, 773-795.
Toullec D., Pianetti P., Coste H., Bellevergue P., GrandPerret T., Ajakane M., Baudet V., Boissin P., Boursier E., Loriolle F., Duhamel L., Charon D. and Kirilovsky J. (1991) The bisindolylmaleimide GF $109203 \mathrm{X}$ is a potent and selective inhibitor of protein kinase C. Journal of Biological Chemistry 266, 15771-15781.

Zetterberg A. and Larsson O. (1985) Kinetic analysis of regulatory events in G1 leading to proliferation or quiescence of Swiss 3T3 cells. Proceedings of the National Academy of Sciences of the U.S.A. 82, 53655369. 